\title{
Possible Location of the Next Major Earthquakes in the Northern Apennines: Present Key Role of the Romagna-Marche-Umbria Wedge
}

\author{
Enzo Mantovani ${ }^{1}$, Marcello Viti ${ }^{1}$, Daniele Babbucci ${ }^{1}$, Caterina Tamburelli ${ }^{1}$, Nicola Cenni ${ }^{2,3}$ \\ ${ }^{1}$ Dipartimento di Scienze Fisiche, della Terra e dell'Ambiente, Università degli Studi di Siena, Siena, Italy \\ ${ }^{2}$ Dipartimento di Fisica e Astronomia, Università degli Studi di Bologna, Bologna, Italy \\ ${ }^{3}$ Dipartimento di Ingegneria Civile, Chimica, Ambientale e Meccanica, Università degli Studi di Bologna, Bologna, Italy \\ Email: marcello.viti@unisi.it
}

How to cite this paper: Mantovani, E., Viti, M., Babbucci, D., Tamburelli, C. and Cenni, N. (2017) Possible Location of the Next Major Earthquakes in the Northern Apennines: Present Key Role of the Romagna-Marche-Umbria Wedge. International Journal of Geosciences, 8, 1301-1314. https://doi.org/10.4236/ijg.2017.811075

Received: September 18, 2017

Accepted: November 6, 2017

Published: November 9, 2017

Copyright $\odot 2017$ by authors and Scientific Research Publishing Inc. This work is licensed under the Creative Commons Attribution International License (CC BY 4.0).

http://creativecommons.org/licenses/by/4.0/

\begin{abstract}
It is argued that in some zones of the Northern Apennines, in particular the Rimini-Ancona thrust system, the Romagna Apennines and the Alta Valtiberina trough, the probability of major earthquakes is now higher than in other Apennine zones. This hypothesis is suggested by the comparison of the present short-term kinematics of the Romagna-Marche-Umbria wedge in the Northern Apennines, deduced by the distribution of major shocks in the last tens of years, with the previous repeated behavior of the same wedge, evidenced by the distribution of major earthquakes in the last seven centuries. The seismotectonics of the Apennine region here considered is closely connected with the larger context that involves the progressive migration (from south to north) of seismicity along the peri-Adriatic zones. The information provided by this study can be used to better manage the resources for prevention in Italy.
\end{abstract}

\section{Keywords}

Peri-Adriatic Seismicity, Northern Apennines, Romagna-Marche-Umbria, Seismotectonics

\section{Introduction}

The convergence between Africa and Eurasia and the roughly westward migration of the Anatolian-Aegean-Balkan system induces the roughly northward displacement of the Adria plate [1]-[7]. This displacement gradually involves the various sectors of the Adriatic plate (Adria), as they decouple from the confining orogenic structures by major earthquakes (Figure 1). Each shock triggers an ac- 


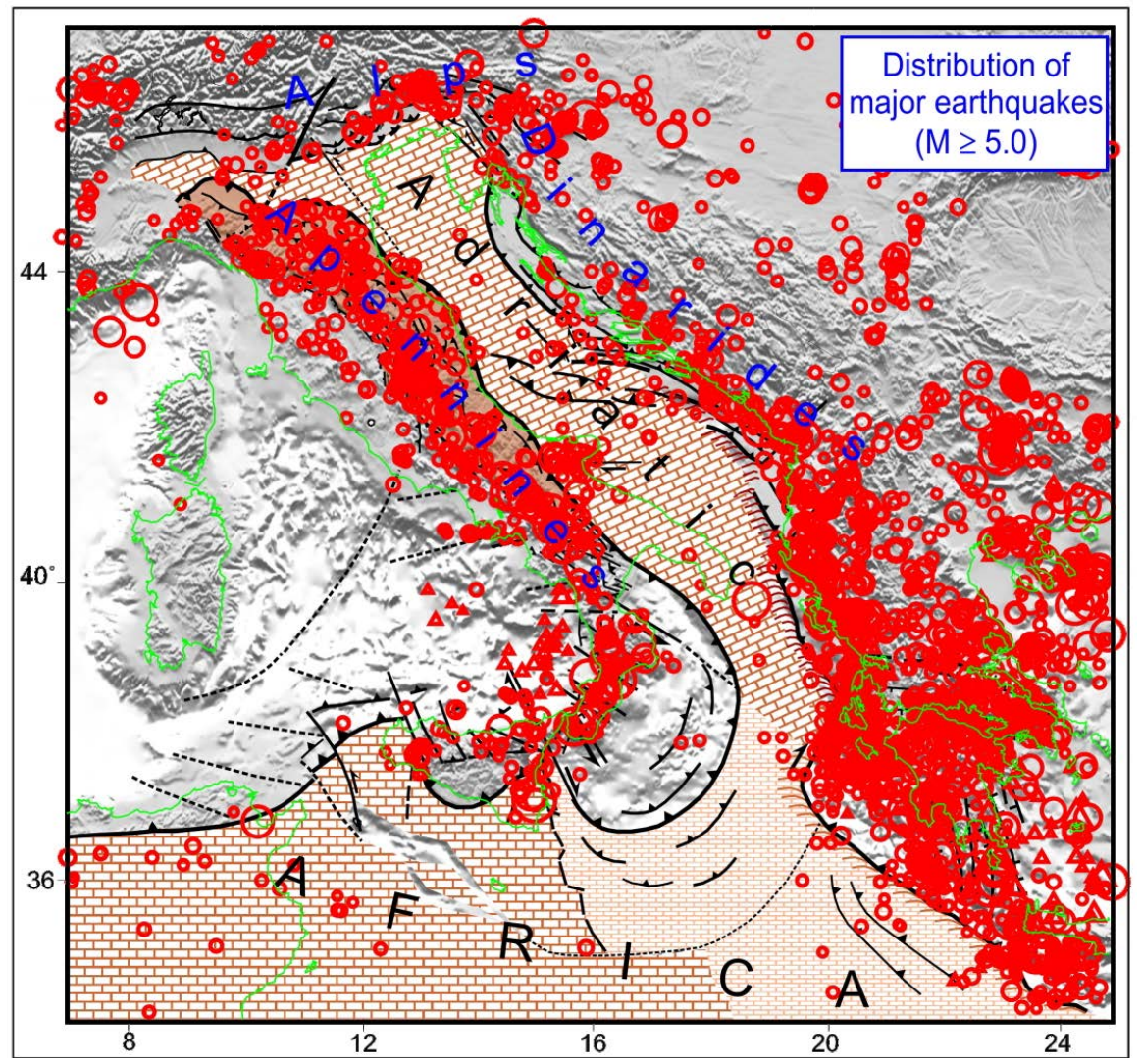

Figure 1. Distribution of major earthquakes that have occurred in the central Mediterranean region since 1300 [15] [16] [17]. Circles and triangles respectively indicate the shallow and deep $(\mathrm{h}>60 \mathrm{~km})$ earthquakes.

celeration of the respective decoupled Adria sector, which then enhances stress at the subsequent, still locked, Adria tectonic boundaries. Thus, considering that the seismic activation of a peri-Adriatic boundary zone may influence the occurrence of strong shocks in nearby sectors [8]-[13], one could expect to observe regularities in the time-space distribution of seismicity along the peri-Adriatic zones. In particular, we have recognized the tendency of seismic activity to migrate from south to north along the eastern (Dinarides) and western (Apennines) boundaries of Adria, up to reach the northern boundary, where such plate underthrusts the Eastern Southern Alps. This interpretation provides plausible explanations for the time patterns of seismicity that developed in the peri-Adriatic zones since 1300 [14] [15] [16] [17].

In this work, we discuss on how the above large scale context may control the distribution of major earthquakes in the Central and Northern Apennines. The seismicity regularity patterns that can be recognized in those zones since 1300 and the recent seismic histories of the study area are then used to tentatively recognize the zones most prone to next strong earthquakes.

\section{Tectonic Setting in the Apennine Belt}

The motion of Adria is accommodated by tectonic activity at the eastern (Hellenides, 
Dinarides), northern (Eastern Southern Alps) and western (Apennines) boundaries of that plate, involving fairly different strain styles (Figure 2).

Underthrusting of Adriatic lithosphere mainly occurs beneath the Northern Hellenides and Southern Dinarides [19] [20] [21] [22].

In the Northern Dinarides the relative motion of Adria with respect to the adjacent structures is mainly accommodated by dextral transpression at the fault system recognized in Istria and Slovenia [23] [24] [25] [26] [27]. In the Eastern Southern Alps, Adriatic lithosphere underthrusts the Alpine edifice [28] [29].

On the western side of Adria, the tectonic context is more complex (Figure 3), mainly due to the fact that the outer (Adriatic) sector of the Apennine chain is undergoing outward extrusion and uplift, in response to the belt-parallel compression induced by the motion of Adria [4] [5] [7] [30] [31]. This deformation has caused the separation of that Apennine sector from the inner (Tyrrhenian) Apennines, which has been accommodated by the formation of a series of troughs along the axial part of the belt [32].

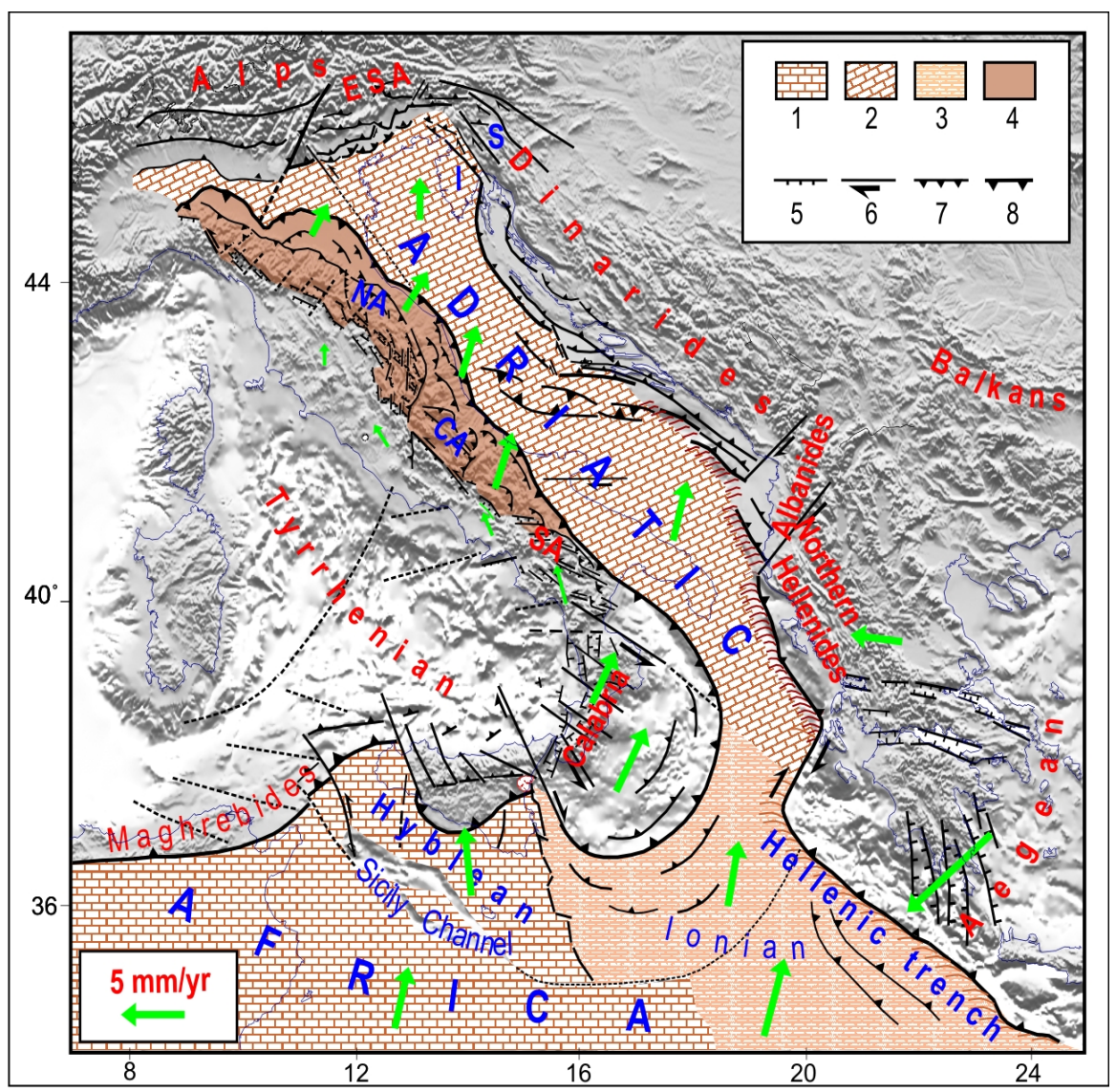

Figure 2. Tectonic sketch of the central Mediterranean region [1] [2] [3] [4] [5] [7] [18]. (1) (2) African and Adriatic continental domains; (3) Ionian oceanic domain; (4) Outer sector of the Apennine belt stressed and carried by the Adriatic plate; (5)-(7) Major extensional, transcurrent and compressional tectonic features; (8) Outer front of belts. Green arrows show a tentative reconstruction of the Quaternary kinematic pattern with respect to Eurasia [2]. CA = Central Apennines; ESA = Eastern Southern Alps; I = Istria; $\mathrm{NA}=$ Northern Apennines; $\mathrm{S}=$ Slovenia; $\mathrm{SA}=$ Southern Apennines. 


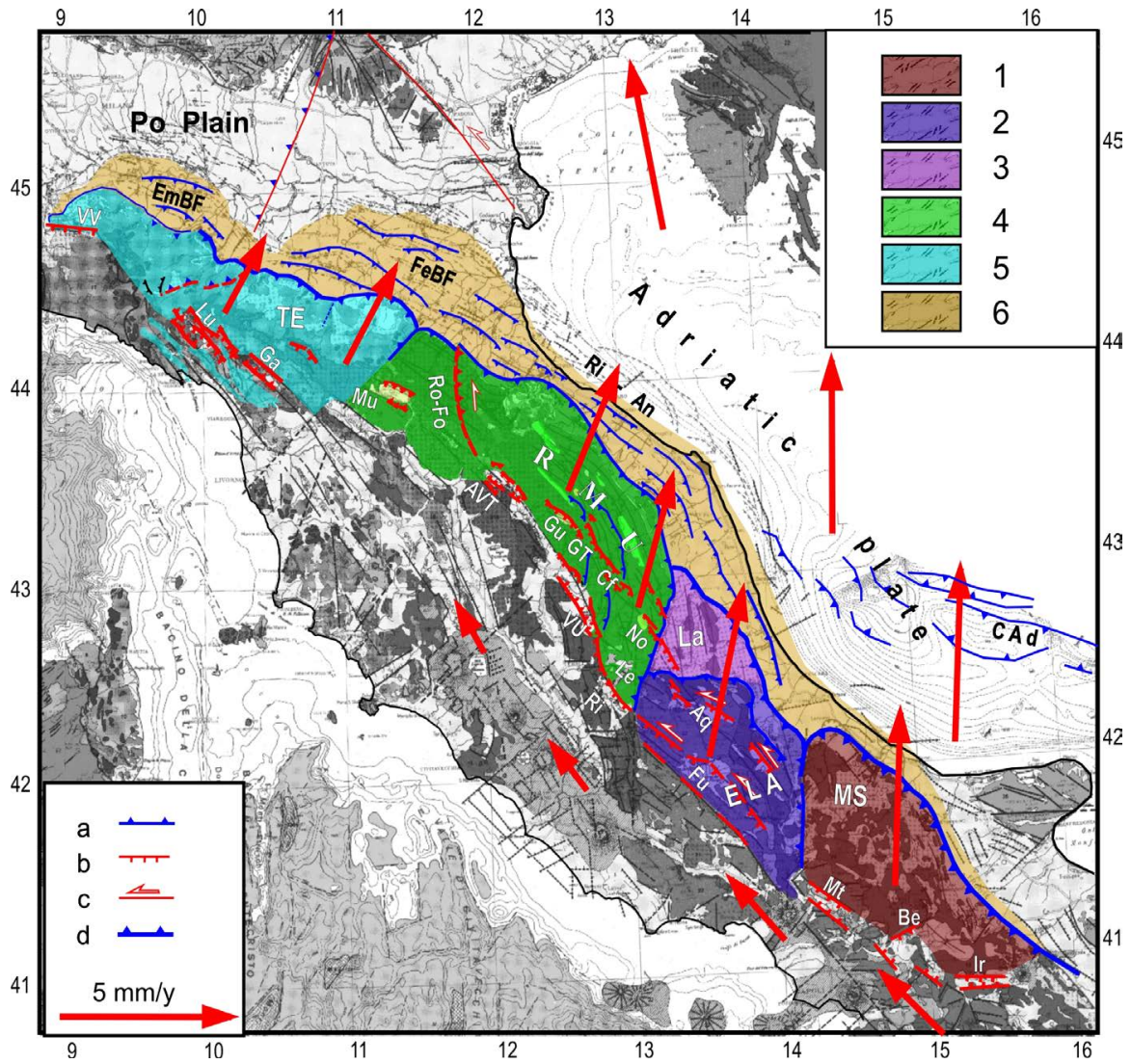

Figure 3. Post-early Pleistocene tectonic setting in the Apennine belt [15]. The outward escape of the Apennine wedges (colored) and adjacent buried folds accommodates belt parallel shortening driven by Adria. (1) Molise-Sannio wedge (MS); (2) Eastern Latium-Abruzzi wedge (ELA); (3) Laga Units (La); (4) Romagna-Marche-Umbria wedge (RMU); (5) Tuscany-Emilian wedge (TE); (6) Outer mostly buried thrusts and folds of the belt; (a)-(c) Main compressional, extensional and transcurrent features; (d) Outer front of the belt. Red arrows indicate the presumed long term average kinematics of Adria and Apennine wedges with respect to Europe. Aq = L'Aquila fault system; AVT = Alta Valtiberina trough; $\mathrm{Be}=$ Benevento fault system; $\mathrm{CAd}=$ Central Adriatic ridge; $\mathrm{EmBF}=$ Emilia buried folds; FeBF = Ferrara buried folds; Fu = Fucino fault system; Ga = Garfagnana trough; $\mathrm{Ir}=$ Irpinia fault system; Le = Leonessa trough; Lu = Lunigiana trough; $\mathrm{Mt}=$ Matese fault system; $\mathrm{Mu}=$ Mugello trough; No-Cf-GT-Gu = Norcia-Colfiorito-Gualdo Tadino-Gubbio fault system; Ri-An = Rimini-Ancona thrust front; Ro-Fo = Supposed fault system in the Romagna Apennines and Forli zone, identified by seismic activity; Rt = Rieti trough; $\mathrm{VU}=$ Valle Umbria trough; $\mathrm{VV}=$ Villalvernia-Varzi.

The more mobile and uplifting parts of the outer belt are the Molise-Sannio (MS) wedge, in the Southern Apennines, the eastern part of the Lazio-Abruzzi carbonate platform (ELA), in the Central Apennines, and the Romagna-Marche-Umbria (RMU) and Toscana-Emilia (TE) wedges, in the Northern Apennines. The inner extensional boundary of the MS wedge is located in the Irpinia, Benevento and Matese zones [33]. A significant evidence of the belt-parallel shortening the Apennines are undergoing since the middle Pleistocene is the strong uplift of the whole belt, involving both main ridge axes, intramontane extensional trough and foredeep basins [34]-[42]. 
In the Central Apennines, the transtensional decoupling between the eastern and western sectors of the ELA wedge is mainly accommodated by the L'Aquila and Fucino fault systems [32] [43]. In the Northern Apennines, extensional tectonics mainly occurs along the internal boundary of the RMU wedge, corresponding to the Alta Valtiberina, Valle Umbra, Leonessa and Rieti troughs and to a youngest almost parallel fault system that develops from the Laga mountains to the Gubbio zone, through the Norcia, Colfiorito and Gualdo Tadino zones [30] [32] [42] [44] [45]. It is worth noting that in the Alta Valtiberina trough the subsidence induced by active normal faulting overcomes the uplift of the belt, as indicated by the depositional pattern of Quaternary fluvial deposits [42].

The Romagna Apennine sector is cut by a major roughly N-S discontinuity, the Romagna-Forli fault system (Ro-Fo), which is mainly revealed by the alignment of epicentres of its numerous seismic activations [30]. The lack of clear morphological evidence of such fault may be imputed to its very young generation (late Pleistocene). The divergence between the TE wedge and the inner Apennines has been accommodated by extensional deformation, and related seismic activity, in the Mugello, Lunigiana and Garfagnana troughs [46] [47] and in the Villalvernia-Varzi fault [48].

The outward extrusion of the Apennine wedges has caused shortening along their buried external fronts, in particular along the outer side of the TE wedge (Emilia and Ferrara arcs), of the RMU wedge (Rimini-Ancona thrusts) and in the Central Adriatic ridge [49] [50] [51] [52].

The kinematic pattern inferred from geological evidence has been clearly confirmed by the results of space geodetic observations, which are described in other papers [31] [53]. The kinematic pattern resulting from such data (Figure 4) indicates that the outer sector of the Apennine chain moves considerably faster (4- $6 \mathrm{~mm} / \mathrm{y}$ ) than the inner Tyrrhenian side of that belt $(1-2 \mathrm{~mm} / \mathrm{y})$. These two belt sectors are also characterized by clearly different orientations of motion, roughly NE ward at the outer side and mainly N to NW ward in the inner western side.

\section{Seismic Histories of Peri-Adriatic Boundary Zones and Tentative Tectonic Interpretation}

The list of major earthquakes that occurred in the main peri-Adriatic zones (Figure 5) since $1300 \mathrm{AD}$ is given in Figure 6.

The supposed migrating seismic sequences along the eastern (Dinaric) and western (Apennine) boundaries of Adria, up to the northern Adria front in the Eastern Southern Alps are evidenced by red circles and arrows (Figure 6).

The first sequence (poorly recognizable) might have started in the middle of the XIV century and then continued through the Central-Northern Apennines and Northern Dinarides, up to reach the northern Alpine front around the beginning of the XV century.

The second sequence was triggered by major earthquakes in the Southern Dinarides around the middle of the XV century and involved very strong earth- 


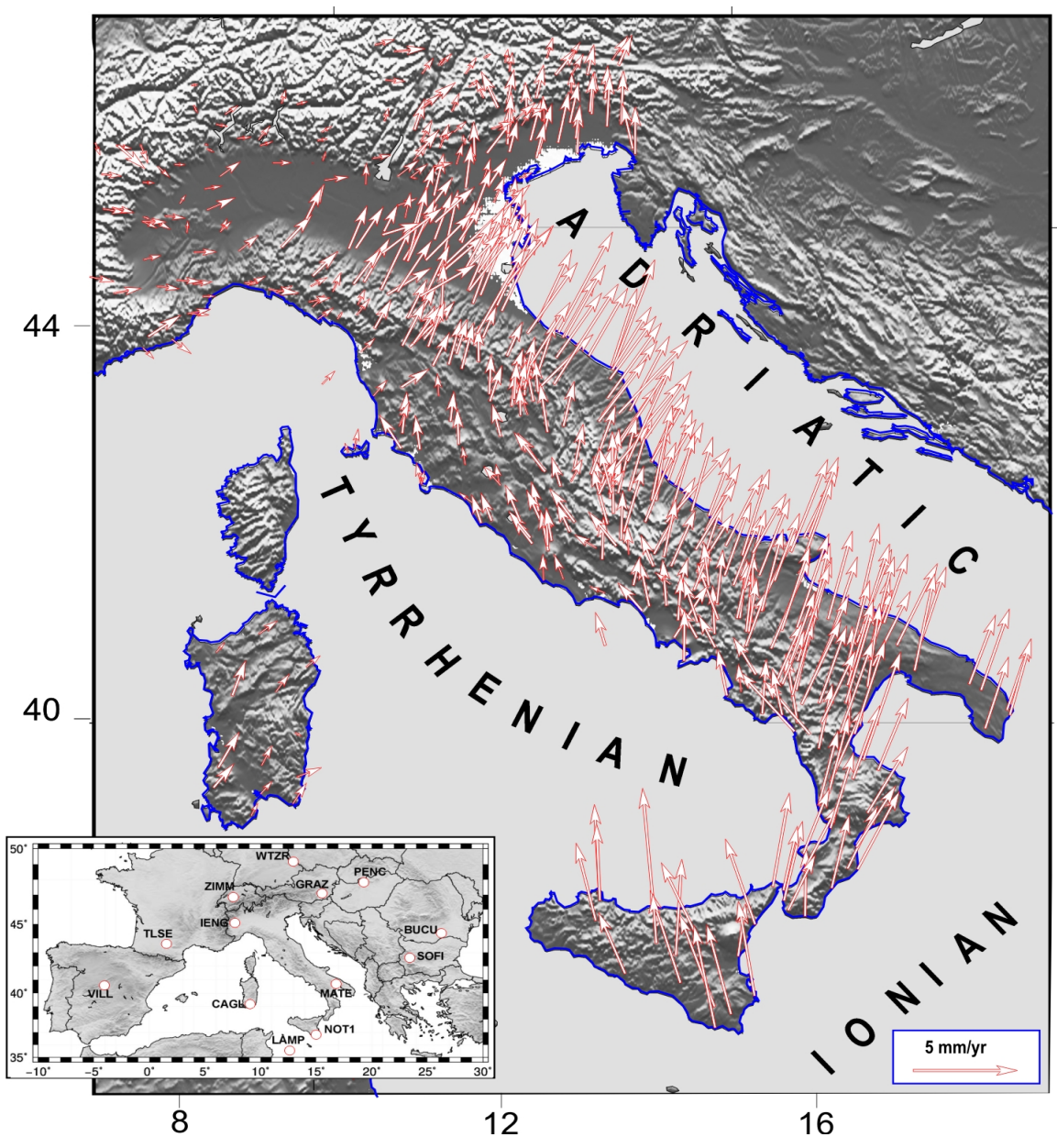

Figure 4. Horizontal velocities (red vectors) of the GPS sites with respect to a fixed Eurasian frame (Euler pole at $54.23^{\circ} \mathrm{N}, 98.83^{\circ} \mathrm{W}, \omega=0.257^{\circ} / \mathrm{Myr}$ [54]. The inset shows the location of the 13 IGS stations that have been used to align the daily solutions of the network to the ITRF 2008 references frame [54]. Details about the analysis of geodetic data are provided by [31] [53].

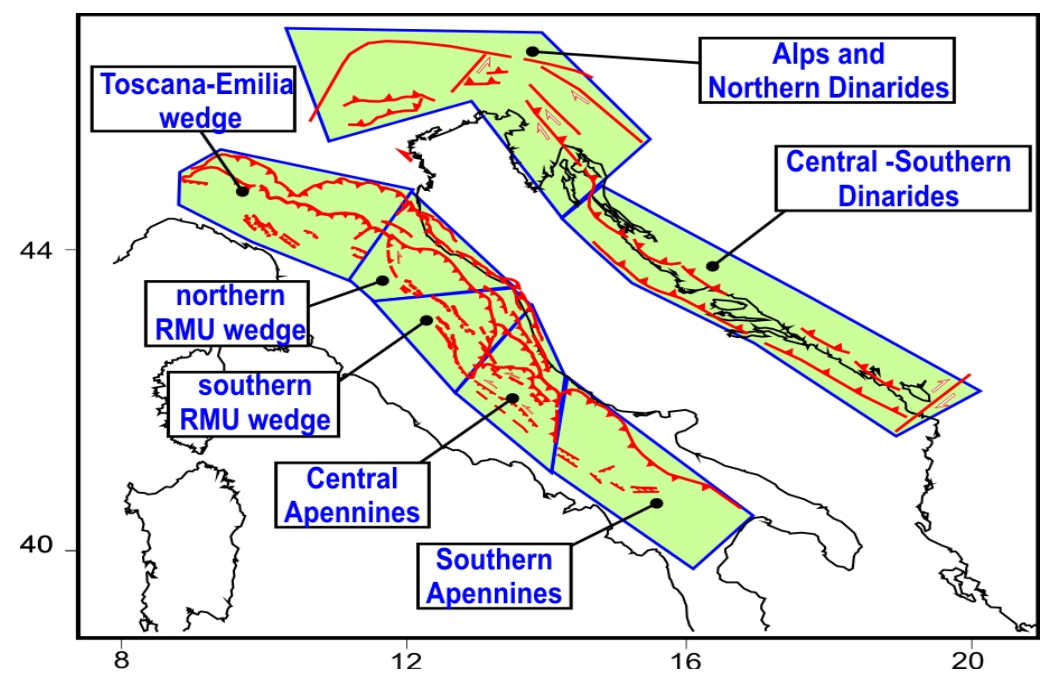

Figure 5. Geometries of the peri-Adriatic zones cited in Figure 6. Tectonic symbols as in Figure 2. 


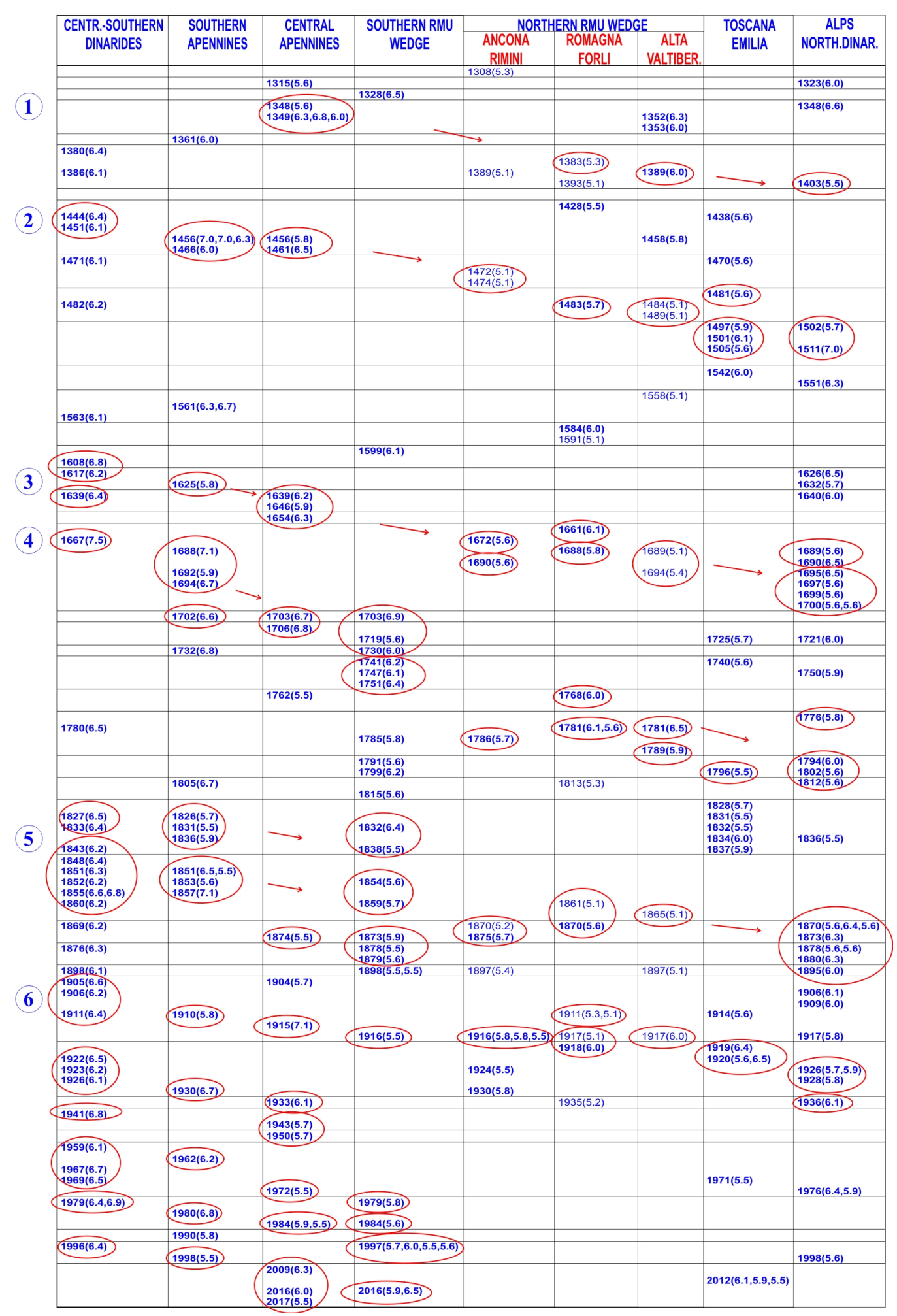

Figure 6. List of major earthquakes $(M \geq 5.5)$ occurred in the peri-Adriatic zones since 1300 AD [15] [16] [55]. Each shock is indicated by the year of occurrence and the magnitude. To avoid mess, the magnitude threshold in the Central-Southern Dinarides is increased to 6 , while in the three fault systems that bound the northern RMU wedge (contoured by the thicker red lines) the threshold magnitude is lowered to 5, in order to better recognize the main seismic activations of those zones (see text). Red circles and arrows help to recognize the events which may be involved in the migrating sequences (numbered from 1 to 6 on the left side of the figure). 
quakes in the Southern Apennines in $1456 \mathrm{AD}$, followed by major shocks in the Central-Northern Apennines and Dinarides, up to reach the northern Adria front around the beginning of the XVI century.

The third sequence started with major earthquakes in the Southern Dinarides and Southern-Central Apennines in the first part of the XVII century and reached the northern Adria front around the end of that century.

The fourth sequence was triggered by a strong shock $(M>7)$ in the Southern Dinarides and three strong shocks in the Southern Apennines. Then, it reached the northern Adria boundary in the second half of the XVIII century.

The fifth sequence was triggered in the first part of the XIX century by a long seismic phase in the Southern Dinarides and Southern Apennines and then reached the Alps and Northern Dinarides around the end of that century.

The last complete sequence started in the Dinarides around the end of the XIX and the beginning of the XX century. Then, it continued with a very strong shock in the Central Apennines (1915 M = 7.1), followed by several major events in the Northern Apennines (1916-1920). The northern Adria front was mainly involved in the 1928-1936 time interval.

In the subsequent period, intense and frequent seismicity occurred in the southern and central Adria boundaries (both concerning the Dinarides and Apennines), while minor activity has involved the Northern Apennines, Northern Dinarides and Eastern Southern Alps (Figure 6).

As far as the last (and still incomplete) seismic sequence is concerned, the activation of fault systems in the Northern Apennines started in 1979 in the Norcia zone. Then, seismic activity continued to involve the northern prolongation of that fault system (Figure 3), with major shocks in the Gubbio (1984), Colfiorito (1997), L'Aquila (2009) and more recently in the Amatrice-Norcia zones in 2016 and 2017 (Figure 6). The seismic activation of such extensional faults may be an effect of the acceleration of the RMU wedge and of the consequent separation of that sector from the inner less mobile Tyrrhenian side of the belt (Figure 3 and Figure 4). This acceleration could have strengthened stresses at the northern boundaries of such wedge, corresponding to the Rimini-Ancona compressional front (Ri-An), the Romagna-Forli transpressional fault (Ro-Fo) and the extensional Alta Valtiberina trough (AVT), as shown in Figure 7. However, this stress increase has not so far been sufficient to activate those faults, as indicated by the lack of significant seismicity since the last strong seismic crisis in the period 1916-1918.

In this context, one could suppose that the seismic breaking of such boundaries zones, and the consequent northward acceleration of the RMU wedge, may represent the most probable next development of the ongoing tectonic setting, aimed at releasing the deformation so far accumulated by the RMU wedge. However, it is obviously difficult to evaluate, even approximately, when the above decoupling process will take place.

In order to get possible insights into the future seismic behavior of the three 


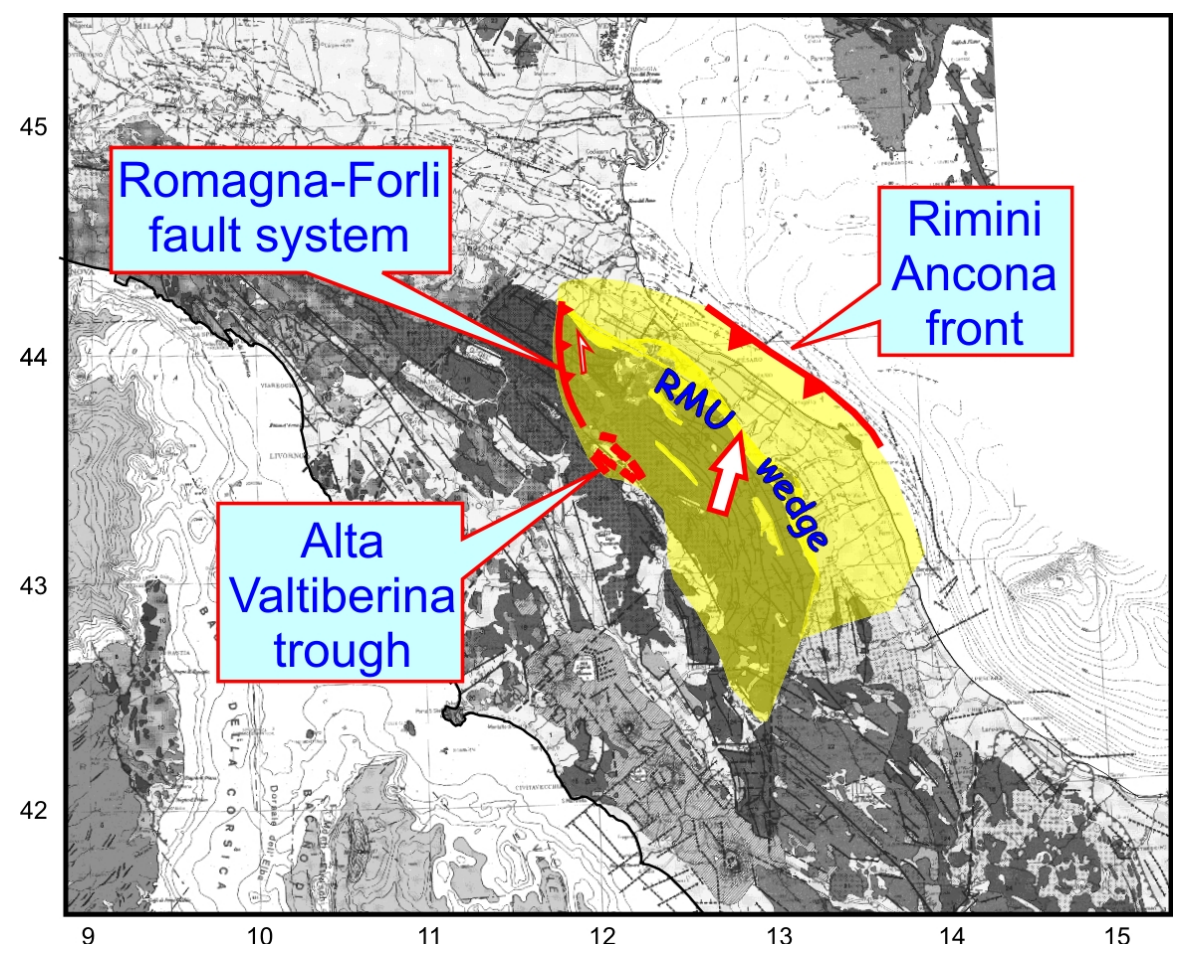

Figure 7. Boundaries of the northern sector of the RMU wedge (yellow). Symbols as in Figure 2. The presumed kinematics of this wedge is indicated by the arrow.

boundary zones cited above, one could observe that such fault systems tend to activate within few years from each other (Figure 6). This phenomenon can be recognized in six short periods (1383-1393, 1472-1489, 1661-1694, 1768-1789, 1861-1875, 1916-1918). The significance of this repeated behavior is underlined by the fact that such multiple seismic activations are mostly separated by long periods of low activity (from several decades to more than a century), with no events with magnitude greater than 5 .

To tentatively predict when the next episode of such regularity pattern may occur, one could consider that the ongoing quiescence, of about hundred years (Figure 6), is the longest so far occurred, except the one that separated the activations of the three zones involved in the second (1472-1489) and the third (1661-1694) migrating sequences.

If the almost coeval activation of the above fault zones could be considered as a systematic phenomenon, one might expect that after the break of one zone the probability of a strong earthquake would significantly increase in the other two zones. This possibility is confirmed, in particular, by what occurred during the seismic crisis that developed in the Northern Apennines after the strong earthquake that hit the Central Apennines (Fucino) in 1915 (Figure 6). In that case the considerably short times that divided the seismic activations of the three RMU boundary zones (about one year) may be explained by the very large strain that was triggered by the large Fucino shock $(M=7.1)$.

To this regard, [9] have shown that the post seismic strain perturbations triggered by the strong shocks that occurred in the above zones from 1915 to 1920 
can plausibly explain the spatio-temporal development of such seismic sequence, involving the activation of the Ri-An, AVT and Ro-Fo fault systems (Figure 7).

\section{Conclusions}

The advanced knowledge so far acquired about the tectonic setting in the central Mediterranean area and its connection with the spatio-temporal distribution of major earthquakes in the peri-Adriatic zones is tentatively used to get information about the most probable location of next strong shocks in the Italian region.

The facts that seismic activity tends to gradually migrate from south to north along the boundaries of the Adria plate (evidenced by the tentative recognition of six main seismic sequences since $1300 \mathrm{AD}$ ) and that in the last period (post 1930) the main decoupling earthquakes mostly occurred in the southern and central sectors of the peri-Adriatic boundaries suggest that at present the occurrence of strong shocks is more probable in the northern peri-Adriatic zones (Northern Apennines, Northern Dinarides and Eastern Southern Alps).

Furthermore, the comparison of the recent seismicity pattern in the Northern Apennines with the ones that occurred in the previous peri-Adriatic seismic sequences suggests that the most probable development of tectonic activity will involve the seismic activation of the fault systems located around the northern part of the Romagna-Marche-Umbria wedge, corresponding to the Ancona-Rimini, Romagna Apennines and Alta Valtiberina zones. In fact, the knowledge of the present tectonic setting suggests that the occurrence of decoupling earthquakes in these zones may allow the northward displacement of the RMU wedge, which seems to be the process that can best accommodate the release of the strain so far accumulated by such structure, stressed by belt-parallel compression in the outer Apennine chain. Whilst the northern boundaries of the RMU wedge are blocked, one can expect that the push of such Apennine sector on the Toscana-Emilia wedge increases strain and stress in this last structure, increasing the probability of earthquakes at the fault systems that lay along its inner and outer boundaries, i.e. the buried Emilia and Ferrara arcs and the Lunigiana and Garfagnana troughs (Figure 3). The results presented in this study can be useful for recognizing the Italian seismic zones most prone to next strong earthquakes, which can help the choice of the most efficient development of a prevention plan.

\section{Acknowledgements}

We thank two anonymous Reviewers for their constructive comments. This work has been supported by Regione Toscana (Italy).

\section{References}

[1] Mantovani, E., Viti, M., Babbucci, D., Tamburelli, C. and Albarello D. (2006) Geodynamic Connection between the Indentation of Arabia and the Neogene Tectonics of the Central-Eastern Mediterranean Region. In: Dilek, Y., Pavlides, S., Eds. Post-Collisional Tectonics and Magmatism in the Mediterranean Region and Asia, Geological Society of America Special Volume 409, 15-41. 
[2] Mantovani, E., Viti, M., Babbucci, D. and Albarello, D. (2007) Nubia-Eurasia Kinematics: An Alternative Interpretation from Mediterranean and North Atlantic Evidence. Annals of Geophysics, 50, 311-336.

[3] Mantovani, E., Viti, M., Babbucci, D. and Tamburelli, C. (2007) Major Evidence on the Driving Mechanism of the Tyrrhenian-Apennines Trench-Arc-Back Arc System from CROP Seismic Data. Bollettinodella Società Geologica Italiana, 126, 459-471.

[4] Mantovani, E., Babbucci, D., Tamburelli, C. and Viti, M. (2009) A Review on the Driving Mechanism of the Tyrrhenian-Apennines System: Implications for the Present Seismotectonic Setting in the Central-Northern Apennines. Tectonophysics, 476, 22-40. https://doi.org/10.1016/j.tecto.2008.10.032

[5] Viti, M., Mantovani. E., Babbucci, D. and Tamburelli, C. (2006) Quaternary Geodynamics and Deformation Pattern in the Southern Apennines: Implications for Seismic Activity. Bollettino della Società Geologica Italiana, 125, 273-291.

[6] Viti, M., Mantovani, E., Babbucci, D. and Tamburelli, C. (2009) Generation of Trench-Arc-Back-Arc Systems in the Western Mediterranean Region Driven by Plate Convergence. Bollettino della Società Geologica Italiana, 128, 89-106.

[7] Viti, M., Mantovani, E., Babbucci, D. and Tamburelli, C. (2011) Plate Kinematics and Geodynamics in the Central Mediterranean. Journal of Geodynamics, 51, 190-204. https://doi.org/10.1016/j.jog.2010.02.006

[8] Viti, M., D’Onza, F., Mantovani, E., Albarello, D. and Cenni, N. (2003) Post-Seismic Relaxation and Earthquake Triggering in the Southern Adriatic Region. Geophysical Journal International, 153, 645-657. https://doi.org/10.1046/j.1365-246X.2003.01939.x

[9] Viti, M., Mantovani, E., Cenni, N. and Vannucchi, A. (2012) Post-Seismic Relaxation: An Example of Earthquake Triggering in the Apennine Belt (1915-1920). Journal of Geodynamics, 61, 57-67. https://doi.org/10.1016/j.jog.2012.07.002

[10] Viti, M., Mantovani, E., Cenni, N. and Vannucchi, A. (2013) Interaction of Seismic Sources in the Apennine Belt. Journal of Physics and Chemistry of the Earth, 63, 25-35. https://doi.org/10.1016/j.pce.2013.03.005

[11] Mantovani, E., Viti, M., Babbucci, D. and Vannucchi, A. (2008) Long-Term Prediction of Major Earthquakes in the Calabrian Arc. Environmental Semeiotics, 1, 190-207. https://doi.org/10.3383/es.1.2.3

[12] Mantovani, E., Viti, M., Babbucci, D., Albarello, D., Cenni, N. and Vannucchi, A. (2010) Long-Term Earthquake Triggering in the Southern and Northern Apennines. Journal of Seismology, 14, 53-65. https://doi.org/10.1007/s10950-008-9141-z

[13] Mantovani, E., Viti, M., Babbucci,.D, Cenni, N., Tamburelli, C. and Vannucchi, A. (2012) Middle Term Prediction of Earthquakes in Italy: Some Remarks on Empirical and Deterministic Approaches. Bollettino di Geofisica Teorica ed Applicata, 53, 89-111.

[14] Mantovani, E., Viti, M., Babbucci, D., Tamburelli, C., Cenni, N., Baglione, M. and D'Intinosante, V. (2015) Present Tectonic Setting and Spatio-Temporal Distribution of Seismicity in the Apennine Belt. International Journal of Geosciences, 6 , 429-454. https://doi.org/10.4236/ijg.2015.64034

[15] Mantovani, E., Viti, M., Babbucci, D., Tamburelli, C., Cenni, N., Baglione, M. and D'Intinosante, V. (2016) Recognition of PeriAdriatic Seismic Zones Most Prone to Next Major Earthquakes: Insights from a Deterministic Approach. In: D’Amico, S., Ed., Earthquakes and Their Impact on Society, Springer Natural Hazard, Springer International Publishing Switzerland, 43-80.

[16] Mantovani, E., Viti, M., Babbucci, D., Tamburelli, C. and Cenni, N. (2016) Tenta- 
tive Recognition of the Italian Seismic Zones Most Prone to Next Strong Earthquakes (as a Tool for Reduction of Seismic Risk). Mistral Service S.a.S., Messina, Italy @ Mantovani Enzo, Viti Marcello, Babbucci Daniele, Tamburelli Caterina, Cenni Nicola.

[17] Viti, M., Mantovani, E., Babbucci, D., Cenni, N. and Tamburelli,'C. (2015) Where the Next Strong Earthquake in the Italian Peninsula? Insights by a Deterministic Approach. Bollettino di Geofisica Teorica ed Applicata, 56, 329-350.

[18] Mantovani, E., Viti, M., Babbucci, D., Tamburelli, C., Cenni, N., Baglione, M. and D'Intinosante, V. (2014) Generation of Back-Arc Basins as Side Effect of Shortening Processes: Examples from the Central Mediterranean. International Journal of Geosciences, 5, 1062-1079. https://doi.org/10.4236/ijg.2014.510091

[19] Louvari, E., Kiratzi, A.A., Papazachos, B.C. and Katzidimitriou, P. (2001) Fault-Plane Solutions Determined by Waveform Modelling Confirm Tectonic Collision in the Eastern Adriatic. Pure Applied Geophysics, 158, 1613-1637.

https://doi.org/10.1007/PL00001236

[20] Aliaj, Sh. (2006) The Albanian Orogen: Convergence Zone Between Eurasia and the Adria Microplate. In: Pinter, N., Grenerczy, G., Weber, J., Stein, S. and Medak, D, Eds., The Adria Microplate: GPS Geodesy, Tectonics and Hazard, NATO Science Series IV-Earth and Environmental Sciences, Vol. 61, Springer, Berlin, 133-149.

[21] Benetatos, C. and Kiratzi, A. (2006) Finite-Fault Slip Models for the 15 April 1979 (Mw 7.1) Montenegro Earthquake and Its Strongest Aftershock of 24 May 1979 (Mw 6.2). Tectonophysics, 421, 129-143. https://doi.org/10.1016/j.tecto.2006.04.009

[22] Kokkalas, S., Xypolias, P., Koukouvelas, I. and Doutsos, T. (2006) PostcollisionalContractional and Extensional Deformation in the Aegean Region. In: Dilek, Y. and Pavlides, S., Eds., Postcollisional Tectonics and Magmatism in the Mediterranean Region and Asia, Geological Society of America, Special Volume 409, 97-123. https://doi.org/10.1130/0-8137-2409-0.97

[23] Markusic, S. and Herak, M. (1999) Seismic Zoning of Croatia. Natural Hazards, 18, 269-285. https://doi.org/10.1023/A:1026484815539

[24] Kuk, V., Prelogovic, E. and Dragicevic, I. (2000) Seismotectonically Active Zones in the Dinarides. Geologica Croatica, 53, 295-303.

[25] Poljak, M., Zivcic, M. and Zupancic, P. (2000) The Seismotectonic Characteristics of Slovenia. Pure Applied Geophysics, 157, 37-55. https://doi.org/10.1007/PL00001099

[26] Burrato, P., Poli, M.E., Vannoli, P., Zanferrari, A., Basili, R. and Galadini, F. (2008) Sources of Mw5+ Earthquakes in Northeastern Italy and Western Slovenia: An Updated View Based on Geological and Seismological Evidence. Tectonophysics, 453, 157-176. https://doi.org/10.1016/j.tecto.2007.07.009

[27] Moulin, A., Benedetti, L., Rizza, M, Jamšek Rupnik, P., Gosar, A., Bourlès, D., Keddadouche, K,, Aumaître, G., Arnold, M,, Guillou, V. and Ritz, J.-F. (2016) The Dinaric Fault System: Large-Scale Structure, Rates of Slip, and Plio-Pleistocene Evolution of the Transpressive Northeastern Boundary of the Adria Microplate. Tectonics, 35, 2258-2292. https://doi.org/10.1002/2016TC004188

[28] Bressan, G., Bragato, P. and Venturini, C. (2003) Stress and Strain Tensors Based on Focal Mechanisms in the Seismotectonic Framework of the Eastern Southern Alps. Bulletin of the Seismological Society of America, 93, 1280-1297. https://doi.org/10.1785/0120020058

[29] Galadini, F., Poli, M.E. and Zanferrari, A. (2005) SeismogenicSources Potentially Responsible for Earthquakes with $M \geq 6$ in the Eastern Southern Alps (Thiene-Udine Sector, NE Italy). Geophysical Journal International, 161, 739-762. 
https://doi.org/10.1111/j.1365-246X.2005.02571.x

[30] Mantovani, E., Viti, M., Cenni, N., Babbucci, D., Tamburelli, C., Baglione, M. and D'Intinosante, V. (2015) Seismotectonics and Present Seismic Hazard in the Tuscany-Romagna-Marche-Umbria Apennines (Italy). Journal of Geodynamics, 89, 1-14. https://doi.org/10.1016/j.jog.2015.05.001

[31] Cenni, N., Mantovani, E., Baldi, P. and Viti, M. (2012) Present Kinematics of Central and Northern Italy from Continuous GPS Measurements. Journal of Geodynamics, 58, 62-72. https://doi.org/10.1016/j.jog.2012.02.004

[32] Piccardi, L., Tondi, G. and Cello, G. (2006) Geo-Structural Evidence for Active Oblique Extension in South-Central Italy. In: Pinter, N., et al., Eds., The Adriamicroplate: GPS Geodesy, Tectonics and Hazard, Springer Verlag, Berlin, 95-108. https://doi.org/10.1007/1-4020-4235-3_07

[33] Ascione, A., Caiazzo, C. and Cinque, A. (2007) Recent Faulting in Southern Apennines (Italy): Geomorphic Evidence, Spatial Distribution and Implications for Rates of Activity. Bollettinodella Società Geologicaltaliana (Italian Journal of Geosciences), 126, 293-305.

[34] Ghisetti, F. and Vezzani, L. (1999) Depth and Modes of Pliocene-Pleistocene Crustal Extension of the Apennines (Italy). Terra Nova, 11, 67-72.

https://doi.org/10.1046/j.1365-3121.1999.00227.x

[35] Argnani, A., Barbacini, G., Bernini, M., Camurri, F., Ghielmi, M., Papani, G., Rizzini, F., Rogledi, S. and Torelli, L. (2003) Gravity Tectonics Driven by Quaternary Uplift in the Northern Apennines: Insights from the La Spezia-Reggio Emilia Geo-Transect. Quaternary International, 101-102, 13-26. https://doi.org/10.1016/S1040-6182(02)00088-5

[36] Bartolini, C. (2003) When Did the Northern Apennine Become a Mountain Chain? Quaternary International, 101-102, 75-80.

[37] Pizzi, A. (2003) Plio-Quaternary Uplift Rates in the Outer Zone of the Central Apennines Fold-and-Thrust Belt, Italy. Quaternary International, 101-102, 229-237. https://doi.org/10.1016/S1040-6182(02)00105-2

[38] Schiattarella, M., Di Leo, P., Beneduce, P. and Giano, S.I. (2003) Quaternary Uplift vs Tectonic Loading: A Case Study from the Lucanian Apennine, Southern Italy. Quaternary International, 101-102, 239-251. https://doi.org/10.1016/S1040-6182(02)00126-X

[39] Ascione, A., Cinque, A., Miccadei, E. and Villani, F. (2008) The Plio-Quaternary Uplift of the Apennines Chain: New Data From the Analysis of Topography and River Valleys in Central Italy. Geomorphology, 102, 105-118. https://doi.org/10.1016/j.geomorph.2007.07.022

[40] Santangelo, N., Di Donato. V., Lebreton, V., Romano, P. and Ermolli, E.R. (2012) Palaeolandscapes of Southern Apennines during the Late Early and the Middle Pleistocene. Quaternary International, 267, 20-29. https://doi.org/10.1016/j.quaint.2011.02.036

[41] Boenzi, F., Capolongo, D., Gallicchio, S. and Di Pinto, G. (2014) Morphostructure of the Lucania Apennines front Between the Basento and Salandrella Rivers (Southern Italy). Journal of Maps, 10, 478-486.

https://doi.org/10.1080/17445647.2014.888017

[42] Pucci, S., Mirabella, F., Pazzaglia, F., Barchi, M.R., Melelli, L., Tuccimei, P., Soligo, M. and Saccucci, L. (2014) Interaction between Regional and Local Tectonic Forcing Along Complex Quaternary Extensional Basin: Upper Tiber Valley, Northern Apennines, Italy. Quaternary Science Reviews, 102, 111-132. 
https://doi.org/10.1016/j.quascirev.2014.08.009

[43] Elter, F.M., Elter, P., Eva, C., Eva, E., Kraus, R.K., Padovano, M. and Solarino, S. (2012) An Alternative Model for the Recent Evolution of Northern-Central Apennines (Italy). Journal of Geodynamics, 54, 55-63. https://doi.org/10.1016/j.jog.2011.11.001

[44] Pizzi, A. and Galadini, F. (2009) Pre-Existing Cross-Structures and Active Fault Segmentation in the Northern-Central Apennines (Italy). Tectonophysics, 476, 304-319. https://doi.org/10.1016/j.tecto.2009.03.018

[45] Galli, P., Peronace, E., Bramerini, F., Castenetto, S., Naso, G., Cassone, F. and Pallone, F. (2016) The MCS Intensity Distribution of the Devastating 24 August 2016Earthquake in Central Italy $\left(\mathrm{M}_{\mathrm{W}}\right.$ 6.2). Annals of Geophysics, 59, Fast Track 5.

[46] Sani, F., Bonini, M., Piccardi, L., Vannucci, G., Delle Donne, D., Benvenuti, M., Moratti, G., Corti, G., Montanari, D., Sedda, L. and Tanini, C. (2009) Late Pliocene-Quaternary Evolution of Outermost Hinterland Basins of the Northern Apennines (Italy), and Their Relevance to Active Tectonics. Tectonophysics, 476, 336-356. https://doi.org/10.1016/j.tecto.2008.12.012

[47] Di Naccio, D., Boncio, P., Brozzetti, F., Pazzaglia, F.J. and Lavecchia, G. (2013) Morphotectonic Analysis of the Lunigiana and Garfagnana Grabens (Northern Apennines, Italy): Implications for Active Normal Faulting. Geomorphology, 201, 293-311. https://doi.org/10.1016/j.geomorph.2013.07.003

[48] Meisina, C. and Piccio, A. (2003) River Dynamics and Slope Processes along a Sector of the Villalvernia-Varzi Line (Northern Italy). Quaternary International, 101-102, 179-190. https://doi.org/10.1016/S1040-6182(02)00100-3

[49] Nicolai, C. and Gambini, R. (2007) Structural Architecture of the Adria Platform-and-Basin System. Bollettinodella Società Geologicaltaliana, Special Issue 7, 21-37.

[50] Boncio, P. and Bracone, V. (2009) Active Stress from Earthquake Focal Mechanisms Along the Padan-Adriatic Side of the Northern Apennines (Italy), with Considerations on Stress Magnitudes and Pore Fluid Pressures. Tectonophysics, 476, 180-194. https://doi.org/10.1016/j.tecto.2008.09.018

[51] Scisciani, V. and Calamita, F. (2009) Active Intraplate Deformation within Adria: Examples from the Adriatic Region. Tectonophysics, 476, 57-72. https://doi.org/10.1016/j.tecto.2008.10.030

[52] Galli, P., Castenetto, S. and Peronace, E. (2012) The MCS Macroseismic Survey of the Emilia 2012 Earthquakes. Annals of Geophysics, 55, 663-672.

[53] Cenni, N., Viti, M., Baldi, P., Mantovani, E., Bacchetti, M. and Vannucchi, A. (2013) Present Vertical Movements in Central and Northern Italy from GPS Data: Possible Role of Natural and Anthropogenic Causes. Journal of Geodynamics, 71, 74-85. https://doi.org/10.1016/j.jog.2013.07.004

[54] Altamimi, Z., Métivier, L. and Collilieux, X. (2012) ITRF2008 Plate Motion Model. Journal of Geophysical Research, 117, B07402.

https://doi.org/10.1029/2011JB008930

[55] Rovida, A., Locati, M., Camassi, R., Lolli, B. and Gasperini, P., Eds. (2016) CPTI15, the 2015 Version of the Parametric Catalogue of Italian Earthquakes. Istituto $\mathrm{Na}$ zionale di Geofisica e Vulcanologia. 